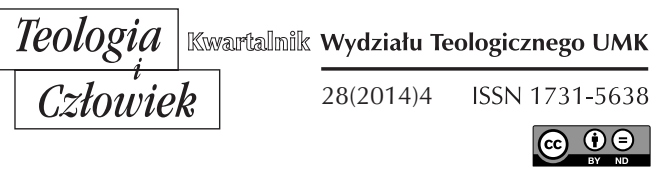

KS. WIESŁAW KAZIMIERUK*

WARSZAWA

\title{
KAPŁAŃSTWO WSPÓLNE W CELEBRACJI EUCHARYSTII
}

DOI: http://dx.doi.org/10.12775/TiCz.2014.059

Wierni przez chrzest włączeni do wspólnoty Kościoła „dzięki otrzymanemu znamieniu przeznaczeni są do uczestnictwa $\mathrm{w}$ kulcie religii chrześcijańskiej, i odrodzeni jako synowie Boży, zobowiązani są wyznawać przed ludźmi wiarę, którą otrzymali od Boga za pośrednictwem Kościoła. Przez sakrament bierzmowania jeszcze ściślej wiążą się z Kościołem, otrzymują szczególną moc Ducha Świętego i w ten sposób jeszcze mocniej zobowiązani są, jako prawdziwi świadkowie Chrystusowi, do szerzenia wiary słowem i uczynkiem oraz do jej obrony" (KK 11) ${ }^{1}$. Włączeni przez sakrament chrztu w kapłaństwo Chrystusowe są przeznaczeni do kultu Bożego. Jako „rodzaj wybrany, królewskie kapłaństwo, naród święty, lud nabyty" (1P 2,9) są przeznaczeni do pełnego, świadomego i czynnego udziału w liturgii (KL 14)², do współudziału w ofiarowaniu Eucharystii, przyjmowaniu sakramentów świętych, modlitwy, dziękczy-

* Ks. Wiesław Kazimieruk jest prezbiterem diecezji siedleckiej, obecnie pracuje w diecezji warszawsko-praskiej jako administrator parafii NSPJ w Warszawie-Falenicy i wykłada liturgikę w seminarium warszawsko-praskim.

${ }^{1}$ Sobór Watykański II, Konstytucja dogmatyczna o Kościele Lumen gentium, w: Sobór Watykański II. Konstytucje Dekrety Deklaracje, Pallottinum, Poznań 2002, s. 113.

${ }^{2}$ Sobór Watykański II, Konstytucja o liturgii świętej Sacrosanctum Concilium, w: Sobór Watykański II. Konstytucje Dekrety Deklaracje, s. 53. 
nienia, świadectwa życia świątobliwego, zaparcia się siebie i czynnej miłości. Powołani są do składania Bogu ofiar duchowych: „Ochrzczeni bowiem poświęceni są przez odrodzenie, namaszczenie Duchem Świętym, jako dom duchowy i święte kapłaństwo, aby przez wszystkie właściwe chrześcijaninowi uczynki składali ofiary duchowe" (KK 10). Mają oni udział we władzy realizowania kultu, który Chrystus określił jako oddawanie czci Ojcu w Duchu i w prawdzie (por. J 4, 23) $)^{3}$. Uczestnicząc w godności kapłańskiej ludu Bożego uprawniającej do składania Bogu prawdziwej ofiary, tj. Chrystusa i łączenia z nią ofiary własnego życia, stają się przez to pośrednikami łaski oraz oddają prawdziwy kult Bogu (por. OWLG 7)4, którego najwyższą formą jest liturgia, a zwłaszcza jej centrum i ośrodek - Eucharystia. Uczestnictwo w tym misterium wiary jest przestrzenią do urzeczywistniania wielorakich funkcji kapłaństwa wspólnego ${ }^{5}$.

\section{CZYNNOŚĆ CHRYSTUSA I KOŚCIOŁA W LITURGII}

Zarówno dokumenty soborowe, jak również teologia posoborowa pojęcie liturgii wiążą z pojęciem Kościoła, a tym samym z eklezjologia ${ }^{6}$. W liturgii bowiem Chrystus jako jedyny i wieczny Kapłan sprawuje swój urząd kapłański nie tylko w Kościele, którego jest Głową, ale także razem z Kościołem jako swoim ciałem (por. KL 7). Liturgia jest zawsze dziełem Chrystusa i Kościoła, niemniej jednak głównym liturgiem jest On sam jako jedyny Pośrednik między Bogiem i ludźmi (por. 1Tm 2, 5; KK 28). W liturgii Chrystus wypełnia swą funkcję Głowy, zwołując zgromadzenie liturgiczne, uświęca poszczególne członki zgromadzenia i czyni z nich lud święty - Kościół, z którym oddaje chwałę swojemu Ojcu. Kościół przyjmuje uświęcające działanie Chrystusa i przez to wypełnia swą funkcję Ciała Chrystusa. Ma to również miejsce we wspólnej

${ }^{3}$ Jan Paweł II, Uczestnictwo świeckich w kaptaństwie Chrystusowym, Os Rom (w.p.) 15: 1984, nr 2, s. 48.

${ }^{4}$ Ogólne Wprowadzenie do Liturgii Godzin, w: Liturgia Godzin, t. 1, Pallottinum, Poznań 2006, s. 28; Por. Cz. Krakowiak, Zgromadzenie liturgiczne jako podmiot celebracji, RBL 42: 1989, s. 172.

${ }^{5}$ Por. J. J. Kopeć, Eucharystia centrum i szczytem życia Kościoła, w: Eucharystia. Misterium - ofiara - kult, red. J. J. Kopeć, Lublin 1997, s. 6-8.

${ }^{6}$ Por. D. Sartore, Chiesa e liturgia, w: Nuovo dizionario di liturgia, red. D. Sartore, A. M. Triacca (NDL), s. 249-259. 
modlitwie uwielbienia Boga Ojca (por. KL 83), a także w złożeniu ofiary w jedności z Chrystusem. Ilekroć bowiem lud Boży celebruje Eucharystię, włącza swój gest ofiarniczy w gest Chrystusowy i wraz z Nim składa Ojcu ofiarę ${ }^{7}$.

W liturgii jako wspólnej czynności całego kapłańskiego Ciała Chrystusa urzeczywistnia się kapłaństwo wspólne ludu Bożego. „Wierni zaś na mocy swego królewskiego kapłaństwa współdziałają w ofiarowaniu Eucharystii, pełnią też to kapłaństwo przez przyjmowanie sakramentów, modlitwę i dziękczynienie, świadectwo życia świątobliwego, zaparcie się siebie i czynną miłość" (KK 11). Liturgia jest szczytem, do którego zmierza cała działalność Kościoła. Jest ona jednocześnie źródłem, z którego wypływa cała jego moc (por. KL 10). Ośrodek zaś życia liturgicznego jak również całego życia chrześcijańskiego, tak Kościoła powszechnego, jak i lokalnego oraz poszczególnych wiernych, stanowi Eucharystia. W niej bowiem "osiąga szczyt działanie, przez które Bóg w Chrystusie uświęca świat, oraz kult, jaki ludzie oddają Ojcu, wielbiąc Go przez Chrystusa, Syna Bożego, w Duchu Świętym" (OWMR 16) . W Eucharystii zawarte jest całe dobro duchowe Kościoła, "to znaczy sam Chrystus, nasza Pascha i Chleb żywy, który przez swoje ożywione przez Ducha Świętego i ożywiające Ciało daje życie ludziom, i w ten sposób usilnie ich zaprasza i pobudza, żeby samych siebie, swoją pracę i wszystkie rzeczy stworzone wraz z Nim składali w ofierze" (DP 5) ${ }^{9}$.

W eucharystycznej Ofierze, która uobecnia tajemnicę Ostatniej Wieczerzy, krzyża i zmartwychwstania Chrystusa, sam Jezus Chrystus jest pierwszorzędnym Kapłanem i głównym darem ofiarnym. Eucharystia jest Jego ofiarą i On sam jest głównym Ofiarnikiem, ale nie jedynym. Chrystus bowiem powierzył swoją ofiarę Kościołowi jako swojej Oblubienicy, przez co staje się ciągle obecna w Kościele tajemnica krzyża. Ofiarę eucharystyczną sprawuje Chrystus wraz ze swoim Kościołem, który $\mathrm{w}$ konkretnym zgromadzeniu jest podmiotem sprawowanej liturgii ${ }^{10}$.

7 Por. A. Durak, Treści uczestnictwa we Mszy Świętej w świetle formut euchologicznych Mszału Rzymskiego dla diecezji polskich (Niedziele Wielkiego Postu i Paschy), Piła 1992, s. 46.

${ }^{8}$ Ogólne wprowadzenie do Mszatu rzymskiego, Pallottinum, Poznań 2004, s. 17.

9 Sobór Watykański II, Dekret o posłudze i życiu prezbiterów Presbyterorum ordinis, w: Sobór Watykański II, Konstytucje Dekrety Deklaracje, Pallottinum, Poznań 2002, s. 484.

${ }^{10}$ Por. A. Paciorek, Eucharystia jako ofiara, w: Jezus eucharystyczny, red. M. Rusecki, M. Cisło, Lublin 1997, s. 122-129. 
W zgromadzeniu eucharystycznym liturgią kieruje biskup - bądź osobiście, bądź przez swoich pomocników prezbiterów. Bez kapłana nie ma zgromadzenia eucharystycznego. On bowiem przewodniczy w modlitwie, głosi zgromadzonej wspólnocie słowo Boże, łączy lud ze sobą w składaniu ofiary Bogu Ojcu przez Chrystusa w Duchu Świętym, rozdaje swoim braciom Chleb życia wiecznego i razem z nimi go spożywa (por. OWMR 92-93). Każdy zaś z uczestników zgromadzenia eucharystycznego ma prawo i obowiązek wnieść wkład we wspólne uczestnictwo, w zależności od stopnia święceń i od spełnianej funkcji (por. KL 14).

\section{UDZIAŁ WIERNYCH W LITURGII EUCHARYSTII}

Sobór Watykański II mocno podkreśla potrzebę pełnego uczestnictwa wiernych $\mathrm{w}$ liturgii, aby nie byli oni

w tym misterium wiary [...] jak obcy lub milczący widzowie, lecz aby przez obrzędy i modlitwy misterium to dobrze rozumieli, w świętej czynności brali udział świadomie, pobożnie i czynnie, byli kształtowani przez słowo Boże, posilali się przy stole Ciała Pańskiego i składali Bogu dziękczynienie; aby ofiarując niepokalaną Hostię nie tylko przez ręce kapłana, lecz także razem z nim, uczyli się ofiarowywać samych siebie i za pośrednictwem Chrystusa, z każdym dniem doskonalili się w zjednoczeniu z Bogiem i wzajemnie ze sobą, aby ostatecznie Bóg był wszystkim we wszystkich (KL 48).

Chrześcijanie bowiem na mocy chrztu świętego są rodzajem wybranym, królewskim kapłaństwem, narodem świętym, ludem nabytym (por. 1P 2, 9). Uczestnictwo w kapłaństwie wspólnym jest główną podstawą teologiczną czynnego udziału wiernych w celebracjach liturgicznych (por OWMR 5).

Termin uczestnictwo (participatio) w odniesieniu do wiernych oznacza, że posiadają oni swoją własną funkcję podczas celebracji liturgicznych. Razem z kapłanem spełniają przewidziane dla nich funkcje liturgiczne $^{11}$. Konstytucja o liturgii świętej, mówiąc o uczestnictwie wiernych w celebracjach liturgicznych, najczęściej posługuje się określeniem czynne uczestnictwo (actuosa participatio). Wpisuje się ono w nurt odnowy litur-

${ }^{11}$ Por. H. Sobeczko, Postawy wewnętrzne $i$ zewnętrzne w czynnym uczestnictwie wiernych we Mszy świętej, RBL 42:1989, s. 208-209. 
gicznej, której zamysłem jest pełne włączenie wiernych świeckich w liturgię Kościoła. Kościół bowiem pragnął dokonać ogólnego odnowienia liturgii, aby lud chrześcijański pełniej z niej czerpał.

Liturgia bowiem składa się z części niezmiennej, pochodzącej z Bożego ustanowienia, i z części podlegających zmianom. Części te $\mathrm{z}$ biegiem czasu mogą, lub nawet powinny, być zmieniane, jeśli wkradły się do nich elementy niezupełnie odpowiadające wewnętrznej naturze samej liturgii albo jeżeli te części stały się mniej odpowiednie. Odnowienie to ma polegać na takim układzie tekstów i obrzędów, aby one jaśniej wyrażały święte misteria, których są znakiem, tak by lud chrześcijański możliwie łatwo mógł je zrozumieć i uczestniczyć w celebracji w sposób pełny, czynny i wspólnotowy (KL 21).

Czynne uczestnictwo wiernych świeckich w liturgii nie może sprowadzać się do swoistego aktywizmu, ale musi być zakorzenione $\mathrm{w}$ naturze sprawowanej liturgii. Jego podstawą jest włączenie przez chrzest w funkcję kapłańską Jezusa Chrystusa.

Uczestnictwo czynne wiernych świeckich w liturgii winno być pełne, co oznacza, że przez udział w niej, mocą misterium paschalnego, człowiek osiąga istnienie i trwanie, objawione w pełni, gdy wszystko zostanie zjednoczone w Chrystusie jako Głowie. W Chrystusie człowiek żyje nadprzyrodzonym życiem i najpełniej urzeczywistnia się to $\mathrm{w}$ misterium Eucharystii. Kolejnymi cechami uczestnictwa w liturgii jest uczestnictwo owocne i wspólne (por. KL 11). Za powyższym charakterem uczestnictwa w liturgii przemawia to, że celebracje liturgiczne powinny wyrażać między innymi ducha wspólnoty, objawiać Kościół jako sakrament jedności. Również sama specyfika natury zgromadzenia liturgicznego wymaga obecności wspólnoty, natomiast celebra wspólnotowa staje się źródłem autentycznego sensu wspólnoty chrześcijańskiej. Konstytucja soborowa o liturgii świętej zaznacza, że udział w liturgii ma być pobożny, łatwy, doskonalszy i uroczysty (por. KL 48). Chodzi bowiem o to, aby lud Boży uczestniczył w liturgii $\mathrm{w}$ duchu wiary i miłości $\mathrm{w}$ odniesieniu do codziennego życia ${ }^{12}$.

12 Por. B. Margański, Uczestnictwo wiernych w liturgii Kościoła, w: Euntes docete, Kraków 1993, s. 96-99. 


\section{FUNKCJE CAłEGO ZGROMADZENIA EUCHARYSTYCZNEGO}

Kościół pragnie doprowadzić wszystkich wiernych do pełnego, świadomego i czynnego udziału w liturgii. Tego domaga się sama natura liturgii i na mocy chrztu lud chrześcijański jest uprawniony i zobowiązany do takiego właśnie udziału. Czynności liturgiczne nie są prywatnymi czynnościami, ale należą do całej wspólnoty Kościoła (por. KL 26). W sprawowanej liturgii każdy spełnia właściwe sobie funkcje, „czy to duchowny, czy wierny świecki - powinien w pełni wykonywać wyłącznie tylko to, co należy do niego z natury rzeczy i na podstawie przepisów liturgicznych" (KL 28). Każdy z uczestników zgromadzenia liturgicznego ma prawo i obowiązek wnieść wkład we wspólne uczestnictwo - w zależności od stopnia święceń i od spełnianej funkcji (por. KL 14; 26).

Całe zgromadzenie liturgiczne, które jest kapłańskim ludem Bożym, nabytym krwią Chrystusa, zgromadzonym przez Pana, spełnia właściwe sobie funkcje. Ogólne wprowadzenie do Mszatu rzymskiego wymienia formy czynnego uczestnictwa, którymi są: słuchanie słowa Bożego, udział w modlitwach i śpiewach, wspólne składanie dziękczynienia i ofiary, wspólne przygotowanie stołu Pańskiego, wspólne zachowanie tych samych gestów i postaw ciała i zachowanie milczenia (por. 34-37).

Postawa słuchania słowa Bożego oparta jest na dialogu, jaki zachodzi między Bogiem a Jego ludem. W liturgii bowiem „Bóg przemawia do swego ludu, Chrystus w dalszym ciągu głosi Ewangelię, lud zaś odpowiada Bogu śpiewem i modlitwą" (KL 33) ${ }^{13}$. Słuchanie słowa Bożego prowadzi do dziękczynienia i współofiary, a także do postaw życiowych zgodnych z duchem Ewangelii. Słowo Boże wskazuje na zbawczy sens znaków świętych, odsłania a zarazem urzeczywistnia misterium Chrystusa $\mathrm{w}$ nich wyrażone. Stąd też spełnia ono funkcję mistagogiczną, wprowadza uczestników liturgii w pełniejsze zrozumienie i przeżywanie tajemnicy Chrystusa w znakach wyrażonej ${ }^{14}$.

Istotnym elementem czynnego uczestnictwa wiernych w liturgii jest wspólna modlitwa i śpiew. Dialogi i aklamacje, jakie mają miejsce w celebracjach liturgicznych, nie tylko są znakiem czynnego uczestnictwa, ale także tworzą relację pomiędzy zgromadzeniem a jego przewodniczą-

${ }^{13}$ Por. R. Kiełczowski, Teologia mszalnej liturgii stowa, w: Eucharystia w duszpasterstwie, red. A. L. Szafrański, Lublin 1977, s. 89.

${ }^{14}$ Por. J. Grześkowiak, Wewnętrzne uczestnictwo we Mszy świętej, w: Eucharystia w duszpasterstwie, red. A. L. Szafrański, Lublin 1977, s. 32. 
cym. Również inne części liturgii, takie jak akt pokuty, wyznanie wiary, modlitwa powszechna, modlitwa Pańska, stanowią te części liturgii, które są bardzo pożyteczne do ukazania i podtrzymania uczestnictwa wiernych, i należą one do całego zgromadzenia (por. OWMR 36). Ogromne znaczenie ma również śpiew, który wyraża i wprowadza w czynne uczestnictwo całego zgromadzenia.

Całe zgromadzenie liturgiczne urzeczywistnia kapłaństwo wspólne również przez postawę dziękczynienia i współofiarowania. Ta postawa czynnego uczestnictwa wiernych w liturgii znajduje swój wyraz najpełniej w Eucharystii, która jest dziękczynieniem. Kościół składa Bogu dziękczynienie i głosi Jego wielkie dzieła. Wynika to z powołania kapłańskiego ludu Bożego, który wezwany jest, aby ogłaszał dzieła potęgi Tego, „który nas wezwał z ciemności do przedziwnego swojego światła” (1P 2, 9). Dziękczynienie, jakie jest zanoszone do Boga między innymi w prefacji mszalnej, buduje Kościół przez to, że wychowuje chrześcijan do właściwej postawy eucharystycznej, to jest dziękczynienia (por. Kol 3, 15). Głoszone uwielbienie przyczynia się do zbawienia człowieka i staje się szkołą prawdy, pokornego uznania zależności człowieka od Boga: „Boże [...] chociaż nie potrzebujesz naszego uwielbienia, pobudzasz nas jednak swoją łaską, abyśmy Tobie składali dziękczynienie. Nasze hymny pochwalne niczego Tobie nie dodają, ale się przyczyniają do naszego zbawienia" (Czwarta Prefacja Zwykła) ${ }^{15}$. Dziękczynienie nie ogranicza się tylko do samej liturgii, ale jest ukierunkowane na przyjęcie stałej postawy życiowej.

Czynne uczestnictwo całego zgromadzenia, poprzez które urzeczywistnia się wspólne kapłaństwo ludu Bożego, uwidacznia się w składaniu $\mathrm{w}$ ofierze niepokalanej Hostii, nie tylko przez ręce kapłana, ale razem z nim. Lud Boży uczy się składać siebie w ofierze wraz $\mathrm{z}$ ofiarą Chrystusa (por. KL 48). Szczytem zaś czynnego uczestnictwa wiernych jest przyjęcie Komunii sakramentalnej. Ofiara bowiem osiąga swą pełnię w uczcie paschalnej. Należą one do tej samej tajemnicy. Jedna łączy się ścisłym węzłem $\mathrm{z}$ drugą.

Pan bowiem w samej ofierze Mszy Świętej ofiaruje się, gdy staje się obecny sakramentalnie jako duchowy pokarm wiernych pod postaciami

${ }^{15}$ Mszat rzymski dla diecezji polskich, Pallottinum, Poznań 2009, s. 56; por. S. Czerwik, Prefacje o Misteriach Chrystusa w Mszale Rzymskim Pawła VI. Geneza i teologia, Warszawa 1984, s. 360-362. 
chleba i wina. I w tym celu powierzył Chrystus Kościołowi tę ofiarę, aby wierni uczestniczyli w niej zarówno duchowo przez wiarę i miłość, jak i sakramentalnie przez ucztę Komunii świętej. Uczestnictwo zaś w Wieczerzy Pańskiej jest łączeniem się z Chrystusem, składającym się za nas w ofierze Ojcu (EM 3) ${ }^{16}$.

Postawy ciała i różnego rodzaju gesty należą do zewnętrznych form uczestnictwa wiernych świeckich w liturgii Eucharystii. Ich wspólnotowy wymiar buduje jedność zgromadzenia. Stąd istotne i ważne w celebracji eucharystycznej jest zachowanie również milczenia w miejscach na to przewidzianych. Milczenie stanowi część akcji liturgicznej i jego natura uzależniona jest od momentu Mszy Świętej, w której ono występuje (por. KL 30). Zgromadzenie eucharystyczne czynnie uczestniczy w liturgii także poprzez wspólny śpiew. W tym względzie doniosłą rolę odgrywa schola lub chór, których zadaniem jest należyte wykonywanie przeznaczonych dla nich części, ,zależnie od rodzaju śpiewu oraz troska o to, aby wierni brali czynny udział w śpiewie" (OWMR 103). Zarówno schola, jak i chór spełniają funkcję służebną wobec zgromadzenia. Wyraża się ona $\mathrm{w}$ ożywianiu wiary za pomocą świętych tekstów i melodii (KL 33). Wszystkich zajmujących się muzyką i śpiewem liturgicznym w zgromadzeniu eucharystycznym - dotyczy to również organisty - powinna cechować troska o właściwe ich wykonanie oraz owocny udział wiernych w śpiewie.

Funkcje całego zgromadzenia eucharystycznego są wyrazem czynnego, świadomego i owocnego oraz wspólnotowego uczestnictwa wiernych świeckich w liturgii Eucharystii. Czynią to oni na mocy kapłaństwa wspólnego, którego podstawą są sakramenty inicjacji chrześcijańskiej: chrzest i bierzmowanie. „Udział ludzi świeckich w potrójnym urzędzie Chrystusa - Kapłana, Proroka i Króla rozpoczyna się wraz z namaszczeniem chrztu, rozwija się przez bierzmowanie, w Eucharystii zaś znajduje spełnienie i pełne mocy oparcie" (ChL 14) $)^{17}$.

${ }^{16}$ Kongregacja Obrzędów, Instrukcja Eucharisticum misterium, w: To czyńcie na moja pamiątę. Eucharystia w dokumentach Kościoła, opr. J. Miazek, Warszawa 1987, s. $156-157$.

17 Jan Paweł II, Posynodalna adhortacja apostolska "Christifideles laici" o powotaniu i misji świeckich w Kościele $i$ w świecie dwadzieścia lat po Soborze Watykańskim II, w: Adhortacje Ojca świętego Jana Pawta II, t. 1, Kraków 1996, s. 287; por. S. Szczepaniec, Liturgię celebruje cata wspólnota (2), „Liturgia Sacra” 2: 1996, nr 3-4, s. 64-67. 
Mówiąc o funkcjach całego zgromadzenia eucharystycznego, należy wyraźnie zaznaczyć, że „każdą zaś prawomocną celebracją Eucharystii kieruje biskup, któremu powierzono zadanie oddawania majestatowi Bożemu kultu religii chrześcijańskiej i kierowanie tym kultem zgodnie z przykazaniami Pana i prawami Kościoła..." (KK 26). Celebrans (biskup lub prezbiter) przewodniczy zgromadzeniu w celebracji Eucharystii. Czyni to w osobie Chrystusa (por. KL 33), przewodnicząc w modlitwie, proklamując orędzie zbawienia, łącząc lud ze sobą w składaniu ofiary Bogu Ojcu przez Jezusa Chrystusa w Duchu Świętym, rozdając swoim braciom Chleb życia wiecznego i spożywając go wraz z nimi. Pełniąc funkcję przewodniczącego, powinien wskazywać na żywą obecność Chrystusa. Jest on bowiem znakiem najwyższego Kapłana, Jezusa Chrystusa, Pośrednika Nowego Przymierza. Jego posługa ma charakter służebny wobec całej wspólnoty zgromadzenia eucharystycznego ${ }^{18}$.

\section{NIEKTÓRE FUNKCJE LITURGICZNE WYPEŁNIANE PRZEZ WIERNYCH ŚWIECKICH W ZGROMADZENIU EUCHARYSTYCZNYM}

Dzięki reformie soborowej Vaticanum II wprowadzono dwie posługi - akolitat i lektorat $\mathrm{w}$ miejsce dotychczasowych święceń niższych i subdiakonatu. Posług tych Kościół zezwolił udzielać także świeckim. W ten sposób jaśniej ukazuje się wzajemne powiązanie wyrażające się w tym, że kapłaństwo wspólne i kapłaństwo urzędowe są sobie wzajemnie podporządkowane: jedno i drugie bowiem we właściwy sposób uczestniczy w jedynym kapłaństwie Chrystusa ${ }^{19}$. Posługa akolitatu przekazywana świeckim $\mathrm{w}$ specjalnym obrzędzie ukierunkowana jest na pomoc celebransowi w zgromadzeniu eucharystycznym. Akolita bowiem pomaga w przygotowaniu wiernych do spełniania funkcji pomocniczych w czynnościach liturgicznych, to jest służącym do mszału, krzyża, świec itp. Przede wszystkim przygotowuje ołtarz i naczynia liturgiczne oraz rozdaje Komunię wiernym (por. OWMR 98). Posługa akolity jest głęboko związana ze sprawowaniem Eucharystii, stąd też zachodzi tu wymóg głębokiej pobożności eucharystycznej.

${ }_{18}$ Por. J. Miazek, Przewodniczenie liturgii i formacja do tej postugi, CT 63: 1993, f. 1 , s. 123 .

19 Por. Cz. Krakowiak, Nowe dekrety papieskie o zniesieniu niższych święceń $i$ święceniach diakonatu, CT 43: 1973, f. 3, s. 81. 
W świetle reformy soborowej wszystkie czynności subdiakona dotyczące słowa należą obecnie do lektora, tak jak posługa przy ołtarzu należy do diakona. Podział ten oparty jest na stwierdzeniu papieża, że są dwie główne posługi w Kościele: posługa słowa (lektora) i posługa ołtarza (akolity) ${ }^{20}$. Posługa lektora nie jest "delegowaną", wypełnianą w zastępstwie tych, którzy mają święcenia, ale własną posługą świeckiego ochrzczonego, któremu została zlecona ${ }^{21}$. Jego zadaniem jest proklamacja słowa Bożego. Dlatego też czyta on przede wszystkim Pismo święte i to jest funkcja własna lektora. Może też wypełnić inne funkcje, np. czytać wezwania modlitwy powszechnej czy też wykonać psalm responsoryjny, a gdy nie ma kantora, kierować śpiewem oraz czynnym uczestnictwem wiernych podczas funkcji liturgicznych, przygotowywać wiernych do godnego przyjęcia sakramentów i czytania Pisma święto w czasie celebracji liturgicznych. Widzimy, że posługa lektora wykracza również poza granice zgromadzenia eucharystycznego, jak chociażby w funkcji uporządkowania wspólnoty liturgicznej. Ważne jest, aby zarówno akolita, jak i lektor byli przygotowani do swojej posługi. Stąd akolita powinien pobożnie uczestniczyć w Eucharystii, przyjmować Komunię świętą, trwać na adoracji Najświętszego Sakramentu. Jego funkcja jest głęboko związana ze sprawowaniem Eucharystii, dlatego wymaga się od akolity głębokiej pobożności eucharystycznej (por. KPK kan. 910 p. 2) 22. Podobnie i lektor w związku z wypełnianiem swojej posługi powinien nadawać się do niej i otrzymać staranne przygotowanie, aby wierni, słuchając słowa Bożego, mogli przyjąć je z wiarą i żywym umiłowaniem.

W zgromadzeniu eucharystycznym istotną rolę odgrywa psałterzysta. Jego zadaniem jest śpiewać lub recytować psalm responsoryjny. Powinien on posiąść sztukę wykonywania psalmodii i zdobyć umiejętność prawidłowej wymowy i dykcji (por. OWMR 102). Funkcja psałterzysty nie jest tożsama z funkcją kantora. Nawiązuje ona do instytucji znanej w starożytności chrześcijańskiej. Różnicę stanowi jedynie fakt dopuszczenia do niej osób świeckich ${ }^{23}$. Zadaniem natomiast kantora - oprócz muzycznego inspirowania całej wspólnoty przez intonowanie śpiewów, podtrzymywanie, dyrygowanie - są rozmaite sposoby dialogowania z ludem poprzez

20 Por.tamże, s. 80.

21 Por. E. Stencel, Lektor i jego liturgiczna postuga, Pelplin 1994; F. Blachnicki, Stużba liturgiczna wedtug Ordo Missae 1969, CT 40: 1970, f. 2, s. 102-103.

22 Kodeks Prawa Kanonicznego, Pallottinum, Poznań 1984, s. 385.

23 Por. G. Skop, Formacja liturgiczno-muzyczna psatterzystów, CT 43: 1973, f. 3, s. 86. 
psalmodię, włączając $w$ to śpiewy procesyjne, na wejście, przygotowanie darów, Komunię świętą, jak również inne formy muzyczne możliwe do zastosowania w liturgii. Zadaniem kantora jest przygotowanie śpiewów całego zgromadzenia. Powinien posiadać on umiejętność prowadzenia chóru, gry na organach oraz służyć fachową pomocą w doborze i ocenie nowych kompozycji liturgicznych.

Spośród pozostałych funkcji liturgicznych należy wymienić tych, którzy zostali wyznaczeni do rozdawania Komunii świętej, jako nadzwyczajni szafarze, oraz ministrantów przeznaczonych do noszenia mszału, krzyża, świec, chleba, wina, wody i kadzielnicy. Poza prezbiterium w zgromadzeniu eucharystycznym występuje szereg funkcji podejmowanych przez wiernych świeckich. Należy do nich między innymi funkcja komentatora, który pomaga wiernym poprzez komentarz czynnie uczestniczyć w Eucharystii, zwłaszcza w liturgii bardziej złożonej. Komentator w odpowiedniej chwili w kilku słowami objaśnia same obrzędy, modlitwy i czytania celebransa lub posługujących. On też kieruje zewnętrznym uczestnictwem wiernych, ich odpowiedziami, modlitwami i śpiewem. Podobnie jak ministrantów, lektorów czy członków chóru, także funkcja komentatora jest w pełni liturgiczna. „Niech więc wykonują swój urząd z taką samą pobożnością i dokładnością, jak to przystoi wzniosłej posłudze i odpowiada słusznym wymaganiom ludu Bożego. Należy więc starannie wychować te osoby w duchu liturgii oraz przygotować do odpowiedzialnego i zgodnego z przepisami wykonywania przypadających każdemu czynności" (KL 29). Komentator, obok celebransa, ukazuje obrzędy liturgiczne jako Boże wezwanie - ukierunkowane na odpowiedź ze strony wiernych. Poprzez komentarz liturgiczny wprowadza wiernych w liturgię i przygotowuje do lepszego jej zrozumienia (por. OWMR 105 b). Także przyjmujący wiernych w drzwiach kościoła, których zadaniem jest wskazanie miejsca i utrzymanie porządku w czasie procesji, czy też ci, którzy zbierają ofiary w kościele, pełnią właściwą funkcję liturgiczną w zgromadzeniu eucharystycznym (por. OWMR 105 c i d). Jak mówi wprowadzenie do Mszału rzymskiego:

godne uznania jest, jeśli wierni przynoszą chleb i wino, które przyjmuje od nich kapłan albo diakon, aby je następnie złożyć na ołtarzu [...] obrzęd przyniesienia ich do ołtarza zachowuje swoją wymowę i duchowe znaczenie. Pożądane jest także przynoszenie przez wiernych lub zbieranie $\mathrm{w}$ kościele pieniędzy albo innych darów przeznaczonych na potrzeby ubogich lub kościoła; składa się je w odpowiednim miejscu obok stołu eucharystycznego (OWMR 73). 
Oprócz wyżej wspomnianych, ważna jest również funkcja ceremoniarza $\mathrm{w}$ zgromadzeniu eucharystycznym, który troszczy się o należytą organizację czynności sakralnych i o wykonywanie ich przez służbę liturgiczną w sposób godny, w należytym porządku i pobożnie (por. OWMR 106). „Świeccy mogą spełniać rozmaite posługi, urzędy i funkcje przysługujące im $\mathrm{w}$ obrębie liturgii [...] czyni[a] to $\mathrm{w}$ zgodzie ze swym specyficznym powołaniem do posługi urzędowej" (ChL 23). Zaangażowanie czynne wiernych świeckich w celebrację Eucharystii pozwala uniknąć jej klerykalizacji, w innym wypadku celebrans pełniłby również funkcje liturgiczne im właściwe. Jeżeli w zgromadzeniu eucharystycznym jest więcej tych, którzy mogą spełniać tę samą funkcję, powinni oni dzielić się między sobą zadaniami (por. OWMR 109-110). „Wszyscy więc, czy to wyświęceni szafarze, czy to świeccy wierni, pełniący swój urząd posługi lub swoją funkcję, winni wykonywać tylko to wszystko, co do nich należy" (OWMR 91). Wymienione tu posługi i funkcje liturgiczne, które mogą pełnić w zgromadzeniu eucharystycznym świeccy, są wymownym przejawem ich uczestnictwa w kapłańskiej posłudze Jezusa Chrystusa i nie jest to forma wyróżniania kogokolwiek. Zawsze pozostaje istotny aspekt służby dla dobra całej wspólnoty Kościoła, który jest Mistycznym Ciałem Jezusa Chrystusa, gdzie On jest Głową tego Ciała, a zgromadzeni Jego członkami.

\section{ZAKOŃCZENIE}

Kapłaństwo wspólne ochrzczonych, które jest udziałem w kapłaństwie Jezusa Chrystusa, urzeczywistnia się przez uczestnictwo w liturgii Kościoła, której centrum stanowi liturgia Eucharystii. Uświadomienie sobie prawdy o włączeniu przez chrzest w funkcję kapłańską Jezusa Chrystusa uzdalnia do czynnego włączenia się w celebrację Eucharystii poprzez współofiarowanie siebie wraz z ofiarą Chrystusa, a także przez podejmowanie wspólnych funkcji całego zgromadzenia, które są wyrazem czynnego uczestnictwa w liturgii. Oprócz tego wierni na mocy udziału w kapłaństwie Jezusa Chrystusa podejmują niektóre funkcje dla dobra całej wspólnoty eucharystycznej. Rozumienie prawdy, że całe zgromadzenie jako Mistyczne Ciało Jezusa Chrystusa, wraz z Nim jako Głową, jest podmiotem liturgii, przyczynia się do czynnego uczestnictwa w niej. 
Streszczenie. Wierni świeccy przez chrzest zostają włączeni w kapłaństwo Chrystusa. Mówimy tu o kapłaństwie wspólnym wszystkich ochrzczonych. Jako „rodzaj wybrany, królewskie kapłaństwo, naród święty, lud nabyty” (1P 2, 9) przeznaczeni są do kultu Bożego, do świadomego i czynnego uczestnictwa w liturgii Kościoła, do współudziału w ofierze Eucharystii, do życia sakramentalnego, modlitwy, dziękczynienia, świadectwa życia i czynnej miłości. Odrodzeni w chrzcie świętym, namaszczeni Duchem Świętym jako dom duchowy i święte kapłaństwo powołani są do składania duchowych ofiar przez wszystkie chrześcijańskie uczynki. Uczestnicząc w godności kapłańskiej, która uzdalnia do składania prawdziwej ofiary, to jest Jezusa Chrystusa i łączenia z nią ofiary własnego życia, stają się przez to pośrednikami łaski i oddają prawdziwy kult Bogu.

Konkretne zgromadzenie eucharystyczne objawia Kościół jako Mistyczne Ciało Chrystusa, gdzie On jest Głową tego Ciała, zgromadzeni wierni zaś poszczególnymi członkami. W liturgii Eucharystii Chrystus wypełnia swą funkcję Głowy przez to, że gromadzi wiernych za pośrednictwem hierarchii i uświęca ich. Czyni z nich lud święty, czyli Kościół i razem z nim oddaje chwałę swemu Ojcu. Czyni to także we wspólnej modlitwie uwielbienia Boga Ojca (por. KL 83).

Całe zgromadzenie w jedności z Chrystusem jest podmiotem sprawowanej liturgii Eucharystii. Liturgia jest zatem dziełem Chrystusa i Kościoła, On zaś jest głównym działającym jako jedyny Pośrednik między Bogiem i ludźmi. W liturgii Eucharystii jako wspólnej czynności całego kapłańskiego Ciała Chrystusa urzeczywistnia się kapłaństwo wspólne ludu Bożego. Wierni na mocy swego kapłaństwa wspólnego współdziałają w ofiarowaniu Eucharystii (por. KL 10). Zgromadzenie eucharystyczne urzeczywistnia kapłaństwo wspólne także przez czynne uczestnictwo w liturgii Eucharystii, wykonując zarówno wspólnie funkcje właściwe zgromadzeniu, jak również przez funkcje spełniane przez niektórych członków zgromadzenia. Żywa świadomość ludu Bożego, zgromadzonego na celebracji Eucharystii, uczestnictwa w kapłaństwie Chrystusa, chroni liturgię przed klerykalizacją, gdzie celebrans od początku do końca czyni wszystko. Czynne uczestnictwo w Eucharystii, wyrastające z kapłaństwa wspólnego, czyni zgromadzenie eucharystyczne żywą wspólnotą.

Słowa kluczowe: kapłaństwo; Eucharystia; liturgia.

Summary: Common priesthood in the celebration of the Eucharist. The secular believers through baptism are incorporated into Christ's priesthood. We are talking about the common priesthood of all the baptized. As "a chosen people, a royal priesthood, a holy nation, a people belonging to God" (1 Peter 2: 9) they are destined for divine worship, for conscious and active participation in the liturgy of the Church, for sharing the sacrifice of the Eucharist, for the sacramental life, for prayer, for thanksgiving, for testimony of life and active love. Reborn in Baptism, anointed with the Holy Spirit, as a spiritual house and a holy priesthood they are called to offer spiritual sacrifices by all Christian works. By participating in the dignity of the priesthood, which enables them to make a real sacrifice, that is Jesus 
Christ and to connect with it the sacrifice of their own lives, through those they become agents of grace and give true worship to God.

Specific Eucharistic assembly reveals the Church as the Mystical Body of Christ, where It is the head of the body, the congregation are individual members. In the liturgy of the Eucharist, Christ fulfils his head function by gathering the believers through the hierarchy and sanctifies them. He makes them a holy person, that is the Church, and together with it he gives glory to his Father. He makes it also in the common prayer of praise to God the Father (cf. SC 83).

The whole congregation in communion with Christ is the subject of the liturgy of the Eucharist. Liturgy is therefore the work of Christ and the Church, and $\mathrm{He}$ is the principal operant as the sole mediator between God and men. In the liturgy of the Eucharist as the common activity of the whole priestly Body of Christ, the common priesthood of the people of God is realized. The believers in virtue of their common priesthood join in the sacrifice of the Eucharist (cf. SC 10). The Eucharistic assembly embodies the common priesthood and by active participation in the liturgy of the Eucharist it performs specific assembly functions, as well as the functions performed by some members of the congregation. Lively awareness of the people of God, gathered for the celebration of the Eucharist, their participation in the priesthood of Christ, protects liturgy from clericalisation, where the celebrant does everything from the beginning to the end. Active participation in the Eucharist, growing out of the common priesthood, makes a living community of the Eucharistic assembly.

Keywords: priesthood; Eucharist; liturgy. 